\title{
The End of the Peasantry: Peasants and Cities in Colonial Java in the Early Twentieth Century
}

\author{
Arif Akhyat \\ Department of History, Universitas Gadjah Mada, Indonesia \\ Email: arief.fib@ugm.ac.id
}

\begin{abstract}
This paper aims to explain the decline of the peasant community in Semarang City, Central Java, by exploring the historical shifts in the city's spatial structures and livelihoods. Spatial changes and the issue of subsistence ethics simultaneously will be used to explain the peasant community's exclusion in the city. In the early of modernization Semarang, peasant economy collapsed by deagrarianization process and creating patterns of domestication, adaptation, and marginalization. This adaptation was necessary to reaffirm longstanding communal bonds that had contributed significantly to the city's historical growth. At the same time, however, the urban peasant community was excluded, as agrarian subsistence ethics required it to remain subordinate, while the city's new economic system limited or failed their social mobility. As a result, the peasant community was increasingly left behind by the city's social transformation. Discussing the end of the peasantry during decolonialization process is as a way to find out the consolidation ability of the peasant community during a depeasantization process. This paper will answer the question how socio-economic modifications were made by peasant to navigate with gigantic changes in the city during decolonialization Semarang? Using the historical method, an analysis of a peasant community seems to be more appropriate for obtaining the process of ending of the peasantry and it took into account for both the continuity and the discontinuity process. This paper is expected to provide new facts that have implications for the writing of the Javanes urban historiography which has never been present in Indonesian historiography.
\end{abstract}

Keywords: city; Semarang; peasant; subsistence ethics; marginal

\section{INTRODUCTION}

Studies of urban peasants, particularly their involvement in the social histories of cities, remain incomprehensive. While peasants in rural areas rely on land as their predominant economic resource, in urban areas they lack such land (Cobban, 1974). Semarang, a city on the northeastern coast of Central Java, experienced significant urbanization in the early twentieth century after it became the Gemeente of Semarang in 1906. Initially, the city had been predominantly agricultural, consisting of dry fields and potential floodlands; according to Nagtegal, its inhabitants at the time were predominantly slaves, peasants, and fishermen (Nagtegal, 1996: 95). However, through the process of urbanization, peasants lost much of their agricultural land, thereby forcing them to adapt to the newly industrialized city and its new social and economic resources (Gooszen, 1999: 80-81).

After the construction of the East Flood Canal (Oost Bandjirkanaal) in 1880 and the West Flood Canal (West Bandjirkanaal) in 1900, moorlands and secondary crops coexisted with increasing urbanity (Boomgaard, 1990). As such, the urban peasant community began responding to the socio-economic challenges of urbanization while still - support by the irrigation provided by the flood canals - working their crops (Bosnak and Koot, 2013: 51-76; van Haal and Koppel, eds., 1949: 276-277; Steven, 1986: 62-63). 
The agricultural economy of 20th-century Semarang implies a peasant community that has been excluded from the study of urban and agrarian history. Even as new transportation facilities and roads were created, easing peasants' access to economic opportunities, it was difficult for them to survive the socio-economic challenges of the city. Conversion strategies were necessary, as the ongoing spatial changes provided only new economic opportunities; urbanization failed to provide them with social mobility. Peasants thus experienced a process of domestication, one of household and marginal family-based management (Elson, 1997).

During this transitional period, farming communities became increasingly marginalized. Peasants, however, could still join labor unions, a situation made possible by peasants' dual role as farmers and laborers. Peasants experienced a process of conversion, one caused both by increased migration from rural areas and the decline of agricultural land in the city (van Schaik, 1986; Cobban, 1988; Colombijn, 1990). Owing to limited opportunities to access non-agricultural (offfarm) economic resources, they existed simultaneously as peasants and as laborers (Tillema, 1916). It is indeed not easy to classify the concept of peasant-laborers; briefly, however, it may be understood as referring to a peasant community with limited agricultural involvement that also held formal employment. The shift from agricultural to industrial labor was also triggered by a shift in peasants status in the agricultural community.

Changes in peasants' status began in 1853 , when they transitioned from compulsory labor to free labor due to increased demand in plantation estates (kultuurdienst), public works (heerendienst), aristocrats (pancendiensten), and villages (desadienst). This has also been attributed to the increased prominence of landless peasants in Semarang, as well as reduced sugar and coffee productivity. Peasant-laborers, recognizing the low wage standards involved in casual and contract labor, stopped accessing employment opportunities; consequently, they began expanding into the city and its industrial sector (Ingleson, 1986). Recent studies of Semarang's urban peasants and their various complexities have failed to incorporate them in their understandings of the city's history. Several studies have explored the conflicts that occurred between social groups with diverse economic and ideological interests, identifying them as causes of social stagnation (Korver, 1985; Cribb, 1991). However, the marginalization of peasants during the urbanization process, as well as their loss of economic opportunities, are among the most important factors to consider as one explores the issue of social class.
In a Weberian sense, classes are social groups causally linked with specific vested interests in goods and services, both of which can only be obtained through the market. According to Swedberg (2003), these vested interests include sexual, speculative, class, emotional, and affective ones (Swedberg, 2003) The market, meanwhile, is understood as involving constructed "labor" and commodities. This study understands labor as a central element of the market, as commodities would mean nothing without it (Worsley, 1978). Status and labor are mutually influential through a dialectical process, one that shapes the economic system. The social structure is thus formed through ownership (Weber; 2002, 75-76). Classcapitalist and labor - dominates dialectical processes, but it is never reversed. This raises the question as to why peasants were unable to exist as a social class in an urban environment.

\section{LAND CHANGES AND SUBSISTENCE LIVING}

A 1938 map of Semarang City (Atlas van Tropish Nederland, 1938) depicts the houses along the main thoroughfares, as well as near the temple, as predominantly brick (steenen bebouwing). Meanwhile, the houses near the Western and Eastern Flood Canal were predominantly made of bamboo, as were those in Randusari and Jomblang Villages. In 1911-1912, the average house in Semarang was a simple one, measuring approximately $51.5 \mathrm{~m}^{2}$; approximately 311 were constructed with bamboo, while 285 used teak/forest wood (wildhout) or brick. Most of these houses had dirt floors; only a small percentage had cement floors. Near the Semarang-Brumbung, SemarangDemak, and Semarang-Kendal railway lines, the average houses were much smaller, measuring only $2 \times 2 \mathrm{~m}$; many housed families of five or more people, and some even accommodated boarders (numpang). A 1916 survey of peasants and urban porters found that, near the East Flood Canal, the average house was inhabited by a husband, a wife, $2-3$ children, boarders, and at least one grandparent. Near the West Flood Canal, meanwhile, the average house was inhabited by a husband, a wife, 1-2 children, boarders, and at least one grandparent (Boomgaard, 1989: 150-155).

Family patterns changed as villages were urbanized and city infrastructure was developed. In the 1940s, as smaller roads between villages were built and existing roads were expanded, the amount of arable land in the city diminished rapidly. This had significant implications for the peasant community's survival. After Semarang formally became a Gemeente in 1906, land issues 
became particularly crucial for peasants, who relied on productive land to earn their livelihoods (Flieringa, 1930: 33-35; Gemeenteblad, 1914). Land commercialization became an increasingly important socio-economic phenomenon, especially as demand for land increased. To ease the classification and appraisement of land, the city government recognized several areas with distinct land prices: Onder District Lor (North Semarang), Onder District Kidul (South Semarang), Onder District Wetan (East Semarang), Onder District Kulon (West Semarang) and Onder District Tengah (Central Semarang). These districts were intended solely as pathokan (guidelines) for determining rental prices, land prices, and location relative to the city center; also considered when determining rental prices were area, location, type of wall, and type of floor. Northern Semarang was home to numerous industrial sites, warehouses, and government offices, which had sprung up near the main road between Semarang and nearby residencies. Much of the land was divided into plots, which could be sold or rented; Karsten (1935) records 615 individual plots. Upon many of these plots, small houses had been built, either for families or boarders; almost $38.6 \%$ of the 3559 houses in the district were boarding houses (verhuiskosten) (Gemeenteblad, 1914). The number of boarding houses suggests that the district was inhabited predominantly by workers and coolies from outside Semarang, including from towns such as Jepara, Rembang, Grobogan, and Purwodadi. These workers stayed in Semarang for 1-week to 1-month periods, going home for holidays or to deal with harvests/ family issues.

In Southern Semarang, only 12 plots were dedicated to residential use; 2,007 houses were found in the district. These plots varied in area, ranging from $672 \mathrm{~m}^{2}$ to $1,400 \mathrm{~m}^{2}$. As this region was fertile, land was controlled mainly by the village administration (Jansen, 1930: 80); consequently, land was not often rented, but provided to residents (Gemeenteblad, 1914: 351-352). Families occupying such land were obliged only to provide 4-6 bundles of grass per month; only if they were unable to provide such grass were they expected to work, receiving 40 cents every day and being charged rent (f. 1.20 / month). Such arrangements appear to have involved mediators/brokers, as the Semarang government received only f. $0.50-1$ per month. In other areas, rental costs were higher; for example, in Sompok and Mlaten, renters were charged between 3-4 cents $/ \mathrm{m}^{2}$ more than in Southern District, while in the hilly Kalisari regionmainly inhabited by Europeans - prices were up to 17\% higher. Also contributing to rental costs were plot size and quality.
High land and house prices were driven particularly prominently by increased demand, which itself was inexorably linked with industrialization and urban development. The majority of landowners were of Chinese heritage, and several villages were controlled almost entirely by certain families. For example, the Kalibanteng area was owned by the families of Be Kwat King and Soe Tjong Be; the Babadan area was owned by Stichting Liem; the Panggung (Penggung) area was owned by Soen Tjoan Tjong Kie; the Karangayu area was owned by Liem Mo Mien; the Mloyo, Penggiling Klein, Kedungbatu, and Simongan areas were owned by the private company "Kian Gwan"; the Tjandi area was owned by Oei Tiong Bing; the Mrican area was owned by Goei Ing Djin; the Randusari area was owned by Oei Tiong Ham; the Batan and Seteran (Peloran) areas were owned by Tan Kie Sing; and the Bugangan area was owned by Sing Goan Lip Kie. Another area, Peterongan, was controlled by a Chinese-owned bank called Bankvereeniging Be Biauw Tjoan. Other lands were owned by Dutch companies; Krapyak was owned by N.V. Handel en Bouw Mij Kembangan; Bulu was owned by N.V. Bouw Mij. Boeloe; and Penggung was owned by N.V. Cultuur Maatchappij Panggoeng. The only private village, wherein all land was owned by the municipal government (Gemeente), was Mlaten. In 1918, there were 22 private villages scattered around the city, many of which were on its borders; the area of these private settlements varied, and each settlement had its own distinct geographical character (Jansen, 1930: 145158; Cobban, 1974: 421).

Descriptions of the situation before the establishment of the Semarang Gemeente Government show serious problems, especially health, sanitation, and environmental issues. Most houses had dirt floors and bamboo walls, with their remaining land to grow fruit trees and other crops. Villages were managed under an autonomous rights system; formal village administration was not implemented until 1938, when the municipal government established the commission for villages (kampongverbeteringscommissie), which was authorized to routinely record population; provide postal services, public health, and housing; and collect taxes,. Under the Regeeringsreglement (RR) model (1854-1940), villages were supposed to be under a particular village authority (desabestuur), but this had never occurred; as such, villages continued to handle taxation and the local economy.

Taxation - including land taxes from rice fields and moorlands - was an important source of tax revenue. The amount of taxes collected depended on the availability of 
irrigation (de water voor zening), location (de hooge boren de zeespiegel) and the availability of drainage (drainage toestand van de grond) (Terra, 1949; Endreisume, 1880). In late 1870, Controller O. Burxabij Lautier reported that, in Grogol District, Semarang Regency, many village heads had been collecting taxes through various means. They received taxes from landowners, most of whom were village elites who also served as village officials (de Inlandsche hoofden) (Eindresume, 1880: 143). This indicates that the turnover from rice fields and moorlands stopped at the village elite. The village governments owned an average of $10 \mathrm{bau}\left(1 \mathrm{bau}=7,096 \mathrm{~m}^{2}\right)$ of land; two residents, Hajji Elias and Kyai Gambir, owned more than 40 bau.

The taxation model used in Grogol District, a tax withdrawal system conducted by the village administration, was ostensibly intended to improve villages; however, village improvements were mostly done through compulsory labor, involving those who could not pay their taxes or had outstanding balances owing. The relationship between village officials and landowners was intensified during the process of leasing, buying, and selling land, which made it possible for more lands to be controlled by outside entrepreneurs. As land commercialization became increasingly widespread in Semarang, land conversion was unstoppable. Village heads thus took a central position, acting not only to accommodate outside workers, but also to sell and lease land, often - especially in Northern Semarang and Southern Semarang - based only on mutual trust (Gemeenteblad, 1914: 350-353). Also influential were village officials who played an important role in the urban farming community, using their central positions and strong socio-economic bargaining power to control the socio-economic processes of urbanization process.

Almost no efforts were made to improve villagers' socio-economic conditions, even when tax collection was hindered by poverty. In October 1920, efforts were made to address the problem of poverty in the city by reducing village autonomy (Cobban 1974: 414-415). Although this was intended to ease village organization and funding through the coordination of the Gemeente Government, it faced significant obstacles, as villagers feared the loss of their solidarity and their traditions (desa verband) (Tillema, 1918). At the time, village residents did not feel a sense of belonging to the city, and as a result they were apathetic about the government's socio-political activities. This isolation laid at the root of various socio-economic problems; poverty resulted in poor sanitation and nutrition, which in turn caused or exacerbated various diseases. Newspapers reported several controversial uses of agricultural and dry land, as well as reports from a pharmacist named F. Tillema that underscored the pressure experienced by urban villages as a result of urbanization and land tenure. Karsten (1935) predicted that physical development - the construction of public facilities and government buildings-would result in the exploitation of land and space, which would consequently disrupt villagers' ability to survive. Land was an economic resource, one that was necessary for accessing industrial and non-formal economic activities. Some studies identified village residents as the the poorest of the poor in the Semarang's socioeconomic system.

Deaths due to disease were high between 1914 to 1918 were high, and - from the Table 1 - it is apparent that most districts had similar numbers of deaths. However,

Table 1. The number of deaths in Semarang, 1914-1918

\begin{tabular}{|l|c|c|c|c|c|}
\hline District & $\mathbf{1 9 1 4}$ & $\mathbf{1 9 1 5}$ & $\mathbf{1 9 1 6}$ & $\mathbf{1 9 1 7}$ & $\mathbf{1 9 1 8}$ (to 3 $\mathbf{3}^{\text {rd }}$ quarter) \\
\hline Southern Semarang & 40 & 175 & 171 & 185 & 254 \\
\hline Eastern Semarang & 24 & 101 & 90 & 196 & 182 \\
\hline Western Semarang & 45 & 198 & 219 & 280 & 283 \\
\hline Central Semarang & 38 & 174 & 183 & 206 & 264 \\
\hline Pedoeroengan & 16 & 78 & 88 & 239 & $46(\mathrm{Q} 1)$ \\
\hline Genoek & 18 & 81 & 91 & 193 & $30(\mathrm{Q} 1)$ \\
\hline Srondol & 15 & 80 & 64 & 66 & $17(\mathrm{Q} 1)$ \\
\hline Mranggen & 15 & 75 & 60 & 263 & $31(\mathrm{Q} 1)$ \\
\hline Karangawen & 19 & 85 & 55 & 195 & $25(\mathrm{Q} 1)$ \\
\hline Kebonbatoer & 18 & 90 & 78 & 191 & $45(\mathrm{Q} 1)$ \\
\hline
\end{tabular}

Source: Tillema, H.F.,1919, Kampong Wee, Groningen, 19 April, p. 10 
the number of deaths was still higher in the city. The municipal government thus began concerted efforts to improve the villages.

Tillema's figures must be viewed critically, as they are not accompanied by demographic data. Nonetheless, they still show how Semarang was affected by poor sanitary and environmental conditions. Tillema explores the process of domestication and marginalization through the socio-economic conditions of the farming community, showing photographs of houses, toilets, and yards filled with garbage and wastewater, highlighting the community's vulnerability. These problems were particularly significant in villages with majority peasantlabor populations, showing that urban peasants lacked access to the city's urbanization processes.

\section{FAILED MOBILITY}

At the dawn of the twentieth century, Semarang's development was increasingly problematic. Not only was the city experiencing environmental issues such as floods, droughts, and sanitation/health problems, but also declining standards of living; this was particularly prominent in the 1910s and 1920s. Peasant and migrant communities, including sugar, railway, and port workers, were the most vulnerable; these industries depended significantly on the international economy, and thus particularly vulnerable to its ebbs and flows. Such workers were no longer able to rent houses or land, and thus forced to establish settlements near the harbor, living in bamboo buildings that housed up to 120 beds each. In one building, owned by the port foreman, each room was filled with 23 workers, who paid 3 cents a night in rent. Many other workers did not get a bed, spending their nights at the market near the port or sleeping on boats.

When rains and floods began to affect their settlements, workers began moving to empty areas that were safe from flooding; others, due to overwork, attempted to avoid the port foreman. Nonetheless, some endured, living together with their neighbors, families and peers, and thus having no problems communicating and socializing. Certain villages-including Jayengaten, Sekayu, Guritan, Bangkong, Batan Mitoto, and Gendingan - had heterogeneous populations. Jayengaten was a special case, as many of its inhabitants followed the teachings of Samin Surosentiko (1849-1914).

In a 1930 map, Ormeling shows a shift in settlement patterns. Some peasants and migrant workers continued to occupy urban areas near the city's main settlements, while others occupied rural areas, leasing land and houses for between f. 1.00 and f. 2.00 (Ormeling, 2006).
Usually migrant workers sought cheap rental properties that could be occupied by more than one worker, mostly settling around Pandean, Ambengan, Karang Toeri, and Karang Sari. Others found properties in the Bojong and Randoesari regions, or around Simpang Lima, a center of European-style buildings and hotels. These labor settlements gradually expanded towards Bendoengan, Bangkong, and Djomblang, then further south towards Tjandi and Ungaran.

The expansion of residential areas, occupied by landless urban peasants, shows how urbanization was eroding the agricultural way of life (Robert, 1990: 353377). Peasants leased land, some of which was sold to the city government, Chinese businessmen, or wealthy indigenous persons (Bumiputra). Not infrequently, vulnerable communities lived in worrisome states. As reported by Colombijn, water frequently entered homes through leaky roofs and other means. Moreover, villages located close to the port were also affected by tidal flooding. As such, it was not uncommon for people to enter the world of prostitution or crime. Sarekat Islam, an Islamic organization, strongly insinuated that the rise of railway lines and urban infrastructure-while still providing new economic opportunities - created new sub-ordinations between the Dutch colonial government and the indigenous population.

\section{DEAGRARIANIZATION IN THE CITY}

Within the context of colonial societies, peasants are often understood as a class that was eliminated through the political games of the elites (Kian, 2006; 233-234). Elite domination has commonly been used to explain the extraction of socio-economic sources. Elites' collaboration, synergy, and cooperation has been identified as a prime reason for the collapse of the peasant economy in the decades following the introduction of the Cultuur Stelsel System (van Niel, 2017). An increased agricultural economy does not necessarily correlate with an increased peasant economy, as particular conditions affected peasants' adaptive ability through what Elson terms the transmogrification process (Elson, 1997).

The extraction process involved a range of elites, including persons of European, Chinese, and indigenous heritage, who created extractive and exploitative alliances (Kian, 2006; 26-34). This became a mechanism for promoting colonialism through "bully tactics" with local communities. Reports from a study of poverty in randomly selected Javanese afdeeling - relying on the opium taxes collected - that employees in 23 afdeeling lived in good condition, 6 afdeeling lived in middling 
conditions, and 4 lived in poor conditions. In his memoir, Pieter Brooshooft's reported that opium had become a major driver of the Semarang economy by 1888, involving large plantations, professional groups, traders, trained workers, and both government and private institutions. Government officials, including assistant wedana and police officers, were also involved in the industrialization and trade of opium (Rush, 1990).

There also occurred significant polarization in the use of agricultural land, with a clear distinction between communal land and private land (the latter of which was predominantly controlled by Chinese businessmen, but also involved Dutch and indigenous landowners) (Husken, 1998). Communal lands were spread across the Javanese countryside, blamed for "stopping" the production process and limiting economic productivity. As communal lands broke down, however, villages were conceptualized differently, becoming centers of agricultural commodities and labor (Goh, 1998).

In the early twentieth century, settlements patterns changed significantly, with certain blocks becoming dominated by particular ethnic groups (Wijken). The Chinese, Dutch (European), Arabs, Indians, and Javanese established individual enclaves within the city. These villages were closed, with checkpoints at each gate, and were prone to social conflict. However, some villages remained communities of urban peasants, where agricultural activities had been historically important. This was particularly prominent in areas such as Bojong, Mlaten, Kaligawe, and the region near the West and East Flood Canals, where freed slaves had been incorporated into the city community.

The expansion of rice farming in Semarang was very prominent in 1888-1928, especially around the eastern and western flood canals. Sajogyo shows that the rice fields expanded from 183,000 hectares in 1888 to 185,000 hectares. Similarly, in West Semarang, even as rice plantations were converted to sugarcane during the Forced Cultivation period, the total area of rice fields only decreased by $2.46 \%$; fields - especially in the Tjandi area - continued to be used for rice, secondary crops, and fruit plants. Although the growth of rice fields in Semarang between 1888 and 1924 was relatively insignificant compared to Besuki, Rembang and Surabaya, which experienced two- and even threefold growth, there was still an important increase in agricultural yield and product diversity.

As time passed, however, the amount of agricultural land shrank, and peasants began migrating from agricultural to non-agricultural labor. This shift was a complex one, in which the agricultural economy and its actors were marginalized, and thus the sector began to be abandoned as workers sought to access employment opportunities in the new industrial sector. As such, industrialization contributed significantly to the uprooting of farming communities and the erosion of the agricultural system. As peasants turned to industrial labor and migrants entered the city, various social problems emerged. However, near the western and eastern flood canals, these socio-economic changes came slowly. Peasants continued to carry out agricultural activities, sometimes using a double crop system, into the 1930s (Terra, 1949). In villages unaffected by settlement improvement programs - even those in the middle of the city-traditional patterns survived. A different pattern emerged in villages affected by the village structuring program (such as Karangasem Village), although some productive trees and secondary crops were still preserved.

Semarang's population density increased rapidly as migrants sought to access opportunities in the industrial and manufacturing sector. These migrants came not only from Grobogan, Demak, Pekalongan, Jepara, and Rembang, but also from Ungaran and Ambarawa. Some studies have argued that migration and urbanization intensified in the liberalization era, not only to take advantage of increased demand for labor increased and new industries, but also to avoid the blights, floods, and heatwaves that plagued rural central Java in the nineteenth century. These migrants, however, brought with them new problems. Some were industrial workers, masons, or coolies, but most worked as farm laborers in areas around the flood canals. This was exacerbated by their lack of the technical expertise demanded by the industrial sector.

Also worth noting is the migration of farm laborers to Semarang's outskirts, especially the coffee plantations of Salatiga and Ungaran and the sugar plantations of Weleri, Comal, Tegal, and Batang. Most of these peasants were women and children, who switched from picking rice to growing coffee (look at the photographs in KITLV's "Samarang” Collection; Scholten, 2009). Consequently, farm labor accumulated on the outskirts of the city, especially after urban land prices increased in 1906. According to data from White, between 1905 1923 migration decreased among men as they became involved in political movements or were captured by the Dutch. As such, by the 1920s women and children needed to financially support their families, either by taking advantage of agricultural opportunities or by making cigarettes/textiles, selling food, or establishing new trade routes.

Women and children peasants who remained in the city were affected by changing city politics, particularly 
Thomas Karsten's attempts at urban planning in the 1920s. Steven criticizes the municipal government's policies as focusing solely on spatial planning, without considering the economic needs of residents. Reduced agricultural land, coupled with limited abilities to enter the industrial sector, led to the separation of nuclear families. At the same time, the rice economy no longer provided peasants with sufficient income, and as such families began planting secondary crops - especially cassava — in dry fields and in their yards.

The integration of migrant peasants into urban communities was a serious problem faced by urban peasants. Disputes expanded into political issues, ultimately resulting in resistance to municipal policies. The areas near the flood canals were particularly prone to social conflict, as were Mlaten and Bojong after the municipal government (under Thomas Karsten) began its urban housing projects. These problems were exacerbated by increased demand for housing.

As a result of the transition from compulsory labor to free labor in 1893, villages no longer had the right to regulate sugar plantations and factories. Consequently, villages needed to reach out to private entrepreneurs to manage labor. Many workers, seeking to access increased economic opportunities, entered contracts with multiple entrepreneurs at the same time. This dishonesty was problematic for village heads and entrepreneurs, and even the possibility of sanctions did not change peasants' labor patterns. Through 1906, many peasant-laborersbetween 1 and 3\%, according to Burger - were bound by contracts and received money, but did not follow the terms of their contracts. Companies thus were very careful in choosing potential workers, recognizing the maladministrative practices of peasants, local authorities, and labor agent groups.

\section{SPATIAL MODERNIZATION AND THE END OF PEASANTRY}

The opening of several Chinese companies and shipping lines in 1862, made possible by the Dutch Trade Act of 1855 , stimulated the creation of urban economic centers in Semarang. Some companies, owned by such significant economic actors as Liem Kiem Lim and Oei Tiong Ham, held a monopoly on the opium trade in Semarang, Surakarta, Yogyakarta, and Surabaya. As railroads linked the cities along the north Javan coast, new urban planning policies were developed, placing cities as centers of governmental, economic, cultural, and artistic activities. Many have argued that the model of urban spatial planning used in north coast of Java was inexorably linked to the Daendels Road, which had facilitated transportation and thereby promoted economic growth in the region. Photographs from the 1920s show that peasants had begun establishing roadside stalls to sell their agricultural products, responding to the growth of industry and cities.

Semarang's geographical conditions and inadequate sanitation contributed to its problems. Tillema, for example, reported numerous cases of malaria, cholera, and typhus in Bojong and Bandungan (Tillema, 1916). Similarly, Mrazek reports that, after the completion of the Daendles Road, incidents of miscarriage and infant mortality increased. Consequently, families chose to migrate, either to the city outskirts or outside of Java. Peasants thus migrated in order to escape an agricultural economic system that was full of disease and environmental risks.

In June 1864, Governor General L.A.J. W. Baron Sloet van Beele began building Java's first railway line. Linking Semarang and Tanggoeng, it began operations on August 10, 1887, under the Netherlands Indies Railway Company (NIS). In 1913, after it proved unprofitable, the line was sold to the Netherlands Indies Railway and Tram Company (SS). Several companies also bid for concessions to construct a railway line. The SemarangJoana Railway Company, for example, completed a line from Semarang to Juana, a small town near Rembang, Central Java, in 1881. SS, meanwhile, constructed lines to the cities of Surakarta (1884) and Cilacap (1888); by 1894, Batavia and Surabaya had been connected by rail. In understanding the rise of the railways in Java, however, it is important to note that infrastructure development was intended to access the market potential of Java's agricultural sector. Expecting to receive a significant return on its investment, the Dutch colonial government spent $f$. 11,919,600 developing infrastructure. Of this, $f$. 8,704,080 was spent on planning, $f .3,215,520$ was spent laying lines, $f .2,000,000$ was spent on carriages, and $f .1,000,000$ was spent on houses.

By 1888 , eight main lines were operating trains, connecting fifteen major cities. These were expected to not only facilitate transportation, but also promote socioeconomic and even political mobilization. Two railroad companies were connecting Semarang with other major cities, enabling the transportation of agricultural products and providing important supplies to sugar cane, tobacco, and rubber plantations. For example, the SemarangCirebon Railway Company established partnerships with 27 companies along Java's north coast, with tracks reaching more than 1,000 small mills. Most of these were operated by Chinese businessmen, though some members 
of the Javanese community were also involved. Even as the railways supported socio-economic relations, and ultimately strong political bonds, however, they also provided peasants with the opportunity to abandon the agricultural and enter industry (Stevens, 1986). Labor absorption within the industrial sector increased through the $1920 \mathrm{~s}$, as reflected in various reports on land that was abandoned by its previous inhabitants (Karsten, 1935).

As such, Semarang was facing an increasingly complicated developmental situation. Not only was it dealing with environmental issues, including floods and droughts, but also urban sanitation and health Between the 1910s and 1930s, quality of life decreased in Semarang City, and as a result many peasants either entered the formal workforce or returned to their areas of origin. Some remained in Semarang, citing the cost of transportation. While these peasants attempted to remain involved in the agricultural sector, they also demanded improved living standards, creating resistance.

Owing to the municipal government's limited ability to manage land, the population of Semarang quickly outpaced the available land (Colombijn, 1990). Migration continued, creating new communities; in 1930, for instance, Semarang was home to a reported 71,937 migrants. Although these migrants had traveled to Semarang for various reasons, most sought employment in the industrial and service sectors. Over time, these migrants occupied much of the arable land in the city, which had been irrigated through the flood canals.

Both migrants and city residents became increasingly reliant on industrial and service sectors, as they had limited capacity to control or own land. Most land was owned by the ethnic Chinese, even though they represented only $12 \%$ of the city's population (in 1920). Little land was available for migrants to become involved in agrarian activities. This was exacerbated by the closure of coffee plantations in 1915, which resulted in more coffee workers entering the city's labor force, as well as by the economic turmoil of the Great Depression.

\section{CONCLUSION}

To conclude, the full implications of this study cannot be fully formulated, as many aspects remain that could add further depth. For now, we may tentatively conclude that several factors contributed to the stagnation and decline of the urban farming community. These factors were not solely economic; they also included land loss and collaborations between village leaders and entrepreneurs that closed peasants' access to agricultural opportunities. Consequently, peasants had no choice but to find alternative sources of income. They did not simply migrate; they converted their labor into new forms. However, throughout the early 20 th century they remained vulnerable as they needed to deal with the rising cost of basic necessities.

Being a subsistence community means when access to the domestic economy loses its ability to preserve local economic resources. Conversion into labor then becomes rational that offers many interests and access, but they still living in limited and subordinated structure.

The complexity of the life of the urban peasant community in Semarang has been lost in the study of urban history and agrarian history. Even more ironic, the existence of the peasant community as a city socioeconomic entity has never been seen as a part of the city's social life. This paper is expected to fill the gap both in agrarian as well as urban historiographies.

\section{ACKNOWLEDGEMENT}

I owe my gratitude to Prof. Dr. Bambang Purwanto, M.A. who initiated and shared with me an interest in the urban agrarian history during colonial Java. I am grateful also to Prof Freek Colombijn, who read the draft and encouraged me to improve the quality of analysis.

\section{REFERENCES}

Algemeen Secretarie (1880). Eindresume, Onderzoek naar de Rechten van den Inlander op den Grond op Java en Madoera. Batavia: Ernst \& Co.

Anonymous (1914). Gemeente Blad, 8(6). Semarang: Gemeente Semarang.

Anonymous (1938). Atlas van Tropisch Nederland. The Hague: Martinus Nijhoff.

Boomgaard, P. (1989). Children of Colonial State: Population Growth and Economic Development in Java, 1795-1880. Amsterdam: Free University Press.

Boomgaard, P., and van Zanden, J.L. (eds.) (1990). Changing Economy in Indonesia, vol. 10 (Food Crops and Arable Lands, Java 1815-1942). Amsterdam: Royal Tropical Institute.

Bosnak, J.E., and Koot, F. X. (2013). Op Reis Met Een Javaanse Edelmen: Een Levendig Portret van Koloniaal Java in De Negentiende Eeuw (18601875). Zutphen: Walburg Pers.

Cobban, J.L. (1974). Uncontrolled Urban Settlement: The Kampong Question in Semarang, 1905-1940. Bijdragen Tot de Taal_Land_en Volkenkunde, 130. The Hague: Martinus Nijhoff.

Cobban, J.L. (1988). Kampungs and Conflict in Colonial Semarang. JSEAS, XIX(2). 
Colombijn, F. (1990). Under Construction: The Politics of Urban Space and Housing during the Decolonization of Indonesia, 1930-1960. Leiden: KITLV Press.

Cribb, R. (1991). Gangsters and Revolutionaries: The Jakarta People's Militia and the Indonesian Revolution, 1945-1949. Honolulu: University of Hawaii Press.

Elson, R.E. (1997). The End of The Peasantry in Southeast Asia: A Social and Economic History of Peasant Livelihood, 1800-1990's. Canberra: Australian National University.

Flieringa, G. (1930). De Zorg voor De Volkshuisvesting in De Stadsgemeenten in Nederlandsch Oost Indie. The Hague: Martinus Nijhoff.

Goh, T. (1998). Communal Land Tenure in NineteenthCentury Java: The Formation of Western Images of the Eastern Village Community. Canberra: Research School of Pacific and Asian Studies.

Gooszen, H. (1999). A Demographic History of the Indonesian Archipelago, 1880-1942. Leiden: KITLV.

van Hall, C.J.J. and van De Koppel, C. (eds.), 1949, De Lanbouw in de Indische Archipel, vol. 2, The Hague: W. van Hoeve.

Husken, F. (1998). Masyarakat Desa dalam Perubahan Zaman: Sejarah Diferensiasi Sosial di Jawa, 18301980. Jakarta: Gramedia Widiasana Indonesia.

Ingleson, J. (1983). Life and Work in Colonial Cities: Harbour Workers in Java in the 1910's and 1920's. Modern Asian Studies, 17(3).

Ingleson, J. (1986). In Search of Justice: Workers and Unions in Colonial Java, 1908-1926. Singapore: Oxford University Press.

Jansen, G., (n.d.). De Decentralisatie en de Grond. Katchman, F.W.M. (ed.), Fijfentwintig jaren decentralisatie in Nederlandsch-Indie, 1905-1930. Semarang: Vereeniging voor Locale Belangen.

Karsten, T. (1935). Over de Semarangsche KonceptBouw-Verordening. Locale Belangen, no. 4 and 5. Semarang: Drukkerij de Bruin.

Korver, A.P.E. (1985). Sarekat Islam: Gerakan Ratu Adil? Jakarta: Grafiti.

Kwee, H.K. (2006). The Political Economy of Java's
Northeast Coast, c. 1740-1800: Elite Synergy. Leiden, Boston: Brill.

Lyon, M. L. (1970). Bases of Conflict in Rural Java. Research Monograph Series, 3. Canberra: University of Canberra.

Nagtegal, L. (1996). Riding the Dutch Tiger: The Dutch East Indies Company and the Northeast Coast of Java, 1680-1743. Netherlands: KITLV.

van Niel, R. (2005). Java's Northeast Coast: A Study in Colonial Encroachment and Dominance. Leiden: CNWS Publications.

Ormeling, F. (2006). School of Atlases for a Colonial Society: The van Gelder/Lekkerkerker School Atlases for the Netherlands East Indies, 1880-1952. Paper presented at the International Symposium on Old Worlds-New Worlds: The History of Colonial Cartography, 1750 1950. Utrecht: Utrecht University.

Roberts, B.R. (1990). Peasants and Proletarians. Annual Review of Sociology, 16. http//www.jstor.org/ stable/2083274.

Rush, J. R. (1990). Opium to Java: Revenue Farming and Chinese Enterprise in Colonial Indonesia, 1860 1910. Ithaca: Cornell University Press.

van Schaik, A. (1986). Colonial Control and Peasant Resources in Java: Agricultural Involution Reconsidered. Unpublished Ph.D. Thesis. Amsterdam: University of Amsterdam.

Scholten, E. L. (2009). Women and the Colonial State: Essays on Gender and Modernity in the NetherlandsIndies, 1900-1942. Amsterdam: Amsterdam University Press.

Steven, T., (1986). Semarang, Central Java, and the World Market, 1870-1900. Nas, P.J.M. (ed.), The Indoensian City: Studies in Urban Development and Planning. Dordrecht, Netherlands, and Cinnaminson, United States: Foris Publications.

Terra, G.J.A. (1949). De Tuinbouw in Indonesia: Erfbouw vruchtenteelt Groenteteelt en Siecteelt. The Hague: W. Van Hieve.

Tillema, H.F. (1916). "Kromoblanda": Over’t vraagstuk van "het Wonen". Kromo `s groote land, 2. The Hague: Electric Drukkerij en Uig. 